Sains Malaysiana 49(3)(2020): 471-481

http://dx.doi.org/10.17576/jsm-2020-4903-02

\title{
Characterization and Impact of Peat Fires on Stabilization of Tropical Lowland Peats in Banting, Selangor, Malaysia
}

(Pencirian dan Impak Kebakaran Gambut kepada Penstabilan Gambut Tropika di Banting, Selangor, Malaysia)

\author{
AZlan ShaH NerWan ShaH*, Khairul AZlan Mustapha \& Roslan Hashim
}

\begin{abstract}
Peat soil is a representative material of soil and well known as rich in organic matters, high compressibility, high porosity and low shear strength. During dry seasons, peat lands will lose lots of water and potentially turn into a tinderbox bringing in fires. When peat forest fires happen, it prompts degradation of humic-rich organic matter eventually reduce the stability of peat soil. The impacts of peat fire on peat soil from degraded area in Banting, Selangor, Peninsular Malaysia, were investigated through the field identification, physical and engineering properties through burnt peat site. The Unconfined Compressive Strength (UCS) result shows the burnt peat soil gained in strength that strongly related to the binder and filler dosage, moisture content of peat and curing time. The value of UCS strength increased with the gain of moisture content of peat samples but the strength tends to decrease when the moisture content exceeds certain point. The organic material changed its physical and chemical structure resulting from the fire event, thus, the capability of the soil to hold water particles is reducing and yielded higher UCS strength of cement-peatstabilization. The most important geotechnical aspects of peat that have effect on stabilization process are natural water content, humification grade, ash content, and pH value. The results also suggested that lateral variation within the peat basin indirectly affects the strength of cement-peat-stabilization. The strength of burnt peat can be considerably improved by stabilization and support the concept of Air Curing Technique.
\end{abstract}

Keywords: Air Curing Technique; cement-peat-stabilization; lateral variation; peat fires, Unconfined Compressive Strength

\section{ABSTRAK}

Tanah gambut adalah bahan wakil untuk tanah dan dikenali sebagai tanah yang mempunyai kandungan organik yang tinggi, kebolehmampatan tinggi, keporosan yang tinggi dan kekuatan ricih yang rendah. Ketika musim kemarau atau kering berlaku, tanah gambut akan kehilangan banyak kandungan air dan boleh menjadi 'bom masa' yang membawa kepada kebakaran. Ketika kebakaran hutan gambut berlaku, ia segera mendegradasi humik kaya bahan organik yang akhirnya mengurangkan kestabilan tanah. Kesan kebakaran gambut di tanah gambut dari kawasan terdegradasi di Banting, Selangor, Semenanjung Malaysia telah dikaji melalui pencirian lapangan, sifat fiziko-kimia dan kejuruteraan melalui kawasan tapak gambut terbakar. Hasil ujian Mampatan Tidak Terkurung (UCS) menunjukkan kekuatan sampel tanah gambut adalah saling berkaitan dengan pengikat dan dos pengisi, kandungan kelembapan gambut dan masa pengawetan. Nilai kekuatan UCS meningkat dengan peningkatan kandungan kelembapan sampel gambut tetapi kekuatannya mulai menurun apabila kandungan kelembapan melebihi titik tertentu. Struktur fizikal dan kimia bahan organik telah berubah akibat daripada kejadian kebakaran, justeru, keupayaan tanah untuk memegang zarah air berkurang dan menghasilkan kekuatan UCS yang lebih tinggi dalam penstabilan simen-gambut. Aspek geoteknikal yang paling penting dalam memberi kesan kepada proses penstabilan adalah kandungan air semula jadi, gred humifikasi, kandungan abu dan nilai pH. Hasil keputusan juga mencadangkan bahawa variasi mendatar dalam lembangan gambut secara tidak langsung mempengaruhi kekuatan penstabilan-simen-gambut. Kekuatan sampel tanah gambut terbakar dapat dikuatkan dengan kaedah penstabilan dan menyokong konsep Teknik Pengawetan Kering.

Kata kunci: Kebakaran gambut; mampatan tidak terkurung; penstabilan-simen-gambut; variasi mendatar; Teknik Pengawetan Kering

\section{INTRODUCTION}

Peat is a natural soil composed of high quantity of organic matter as it is largely formed by the accumulation of decaying plants materials. Tropical lowland peats commonly incorporate undecomposed and partially decomposed branches, logs and/or twigs. These peats shape a fragile ecosystem that is domed in form and nearly purely organic (Paramananthan 2011). Peats are formed by way of constrained decomposition hence, the build-up of natural soil materials. Natural substances are formed by biochemical processes and soil formation developed after the physical (water saturated or anaerobic condition) and 
anthropogenic processes, whereas the process of organic matter accumulation are mainly controlled by environmental conditions, climate and ecosystems (peat swamps, bog or mires) in which the peat is deposited. Morphology of peat generally was identified based on the thickness of peat itself. Lowland organic (histosol) and peat soil was classified into two (2) terminology which are topogambist/ topogenous (peat thickness $<150 \mathrm{~cm}$ ) and ombrogambist/ ombrogeneous (peat thickness $>150 \mathrm{~cm}$ ) as described by Melling (2016) and Paramananthan et al. (1984). In contrast, the United States Department of Agriculture has portrayed soil composes as organic/natural soils if more than half of the upper $80 \mathrm{~cm}$ of the soil is organic if organic soil material of any thickness lays on rock on fragmental material having interstices loaded with organic material (Murtedza et al. 2002). Peatland is portrayed by way of excessive terrestrial and aquatic biodiversity (Yule 2010). In Malaysia, peatland is distributed in low-lying areas for approximately 2.6 million hectares (Melling 2016). The peat development in Selangor, Peninsular, Malaysia have a propensity to occur in the river basins of Sungai Selangor in the north and Sungai Langat in the south.

With the transformation of broad peat land territories over the most recent couple of decades, an expansive territory has been left surrendered and degraded. Forest fire represents a major threat to these areas. Some areas have suffered frequent fires and are overwhelmed by herbaceous vegetation with little tree recovery. During a peat fire event, the temperature at ground level may enlist as high $400^{\circ} \mathrm{C}$, and the temperature at $5,10,20,30,40 \mathrm{~cm}$ below ground level can achieve $200,90,60,50$, and $45^{\circ} \mathrm{C}$, respectively (Usup et al. 2004). The fire can keep on smouldering for a quite a while and spread along the side and descending to profundities of 20-60 $\mathrm{cm}$ to form a bowl-shaped depression (Kon et al. 2012). Fire gave an incredible effect on soil condition in the peat swamp deposit. The heat produced can sterilize the peat soil, and it causes up to $90 \%$ mass loss in the burnt layers (Rein et al. 2008). A study that conducted in burnt peat area in Selangor, Peninsular Malaysia, conclude that the water table and mean peat moisture enlisted more than $30 \mathrm{~cm}$ (above ground level) and 500\% (w/w), respectively, during rainy season (Nuruddin et al. 2006). Peats are problematic soils recognized for their high compressibility and occasional shear strength and are fallacious for construction and foundation purposes. Consequently, it is far necessary to enlarge understanding of the geotechnical properties and mechanical behaviour of burnt tropical peat soils and possibly the use of the stabilized form of peat soils, for preferred construction and basis function especially in degraded area.

\section{MATERIALS AND METHODS}

\section{MATERIALS}

In this study, 8 samples of burnt peat from various locations were collected from a Busut Asli Village zone in Banting,
Selangor area at depth ranges from 0.00 to $0.50 \mathrm{~m}$, labelled as MP-1 to BP-6 (Figure 1). Peat forest areas are identified as undisturbed area from combustion either by natural or man-made fires while burnt peat area (originally peat forest area) are categorized as area with significant fire impacts resulting changes in the chemical and physical structure of in situ peat. All the samples were first described in field and then transferred to the laboratory for further investigation of their physical and engineering properties. Mineral soil in the admixtures form of clays, silts and fine grain sands were collected near to the study area that acting as filler material in cement-peat stabilization. These combinations were utilized instead of well-sorted sand to minimise the occurrence of void spaces inside the stabilized soil structure (Zulkifley et al. 2014).

\section{VON POST CLASSIFICATIONS}

All samples in the field were assessed using modified system that adapted from Van Post Classification (1922) as related in Chapter 8.1.1 of the 'Guideline for Engineering Geological Investigation in Peat and Soft Soils' (Mineral and Geoscience Department 2007). The Von Post Squeeze Test results were assigned based on the Von Post degree of Humification with specific values between $\mathrm{H} 1$ to H10. The decomposition degree of peat is the proportion of the matter which has lost its cellular structure due to the decomposition of plant residues. The degree of humification test was made based on the appearance of soil water that extruded when a sample of peat soil is squeezed in the hand (Andriesse 1988; Zulkifley 2014).

\section{PHYSICO-CHEMICAL PROPERTIES}

The Natural Moisture Content (NMC) of burnt peat soil samples was observed by drying the soil sample in an oven at a consistent temperature of $55^{\circ} \mathrm{C}$ for 3 days in line with BS1377: 1990, Test (A) as used by Zulkifley (2014). The peat samples will gradually lose moisture without altering their structure. Then, the determination of the Organic Content (OC) test was conducted as a percentage of ovendried mass as per ASTM D 2974. Organic content is a dimension of peat purification from any mineral component, thus it is essential to categorize the peat that associated to the morphology of peat deposition. Ash content material of a peat or natural organic soil sample is determined by means of igniting the oven-dried sample of the moisture content determination in a muffle furnace at $440^{\circ} \mathrm{C}$ as in line with ASTM D2974-14, Test (C). The analysis of soil $\mathrm{pH}$ was carried out in accordance with the British Standard 1377: 1990 to identify the acidity or alkalinity of the peat.

\section{GEOTECHNICAL PROPERTIES}

The bar linear shrinkage (Ls) was conducted followed by means of British Standard BS 1377-1990: Part 2. The shrinkage mould crammed by peat soil sample with linear measurement of $140 \mathrm{~mm}$ and placed in the oven at consistent temperature of $55^{\circ} \mathrm{C}$ for 2 days. Unconfined 


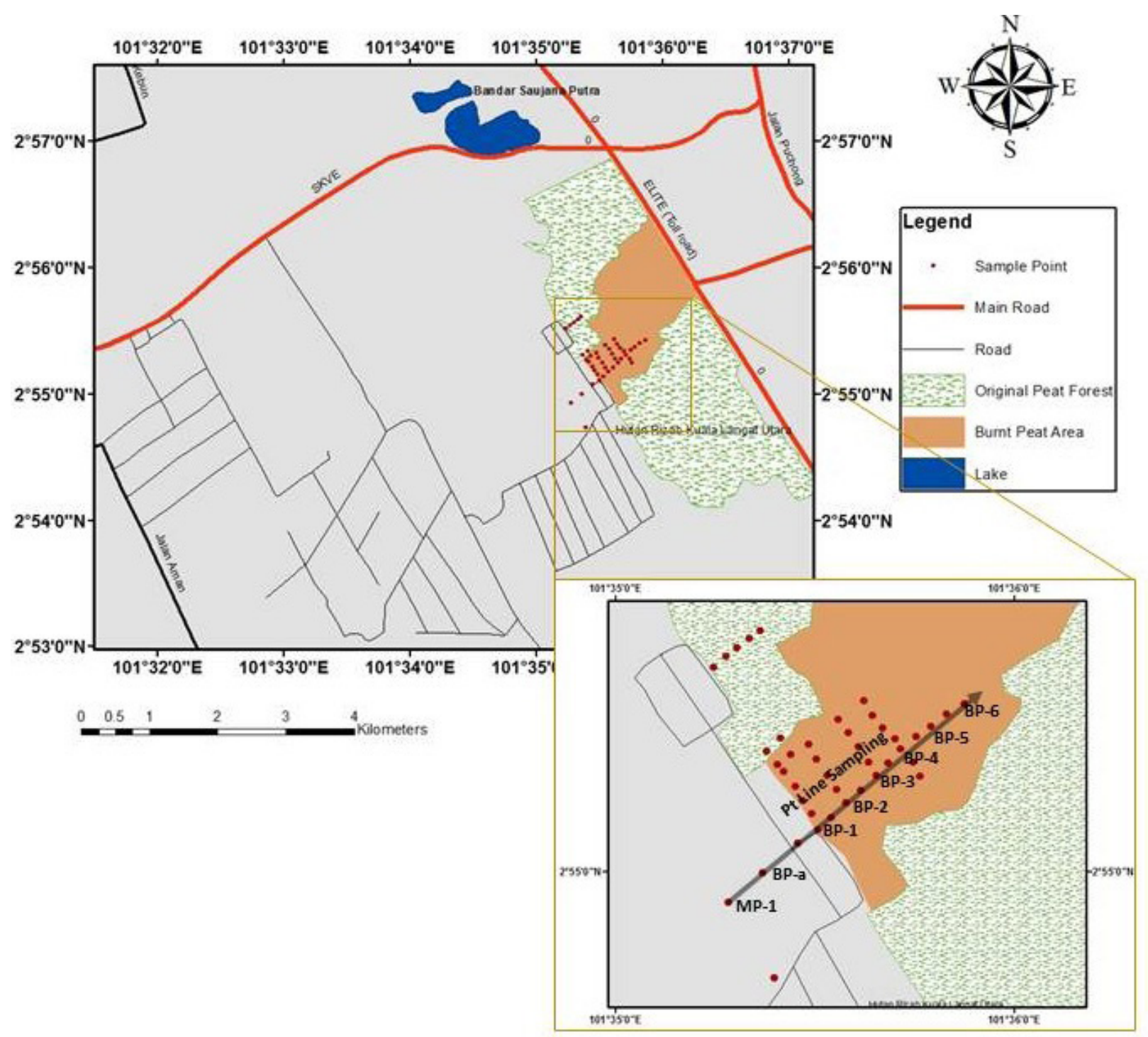

FIGURE 1. Map of project area showing the sampling location of burnt peat soil samples collected

Compressive Strength (UCS) test has been conducted as per BS 1377-1990: Part 7 to determine the total of shear strength.

\section{PRINCIPLES OF THE UNCONFINED COMPRESSIVE STRENGTH TEST}

To characterize the strength behaviour of stabilized burnt and undisturbed peat, 6 units of specimens of different curing duration; 14 and 28 days had been prepared. The curing duration has been selected based on the strength of stabilized peat that normally shows an apparent strength increment after 14 days of curing period (Wong 2010; Zulkifley 2014). Each set of samples were consisted of 100 $\mathrm{g}$ of burnt peat sample with natural (field or in situ) moisture content, $25 \mathrm{~g}$ of mineral soil filler (MSF) as a filler and $20 \mathrm{~g}$ of Ordinary Portland Cement (OPC) as a binder as explained in Table 3. Samples $38 \mathrm{~mm}$ in diameter and $76 \mathrm{~mm}$ in length were used in the experiment as described in Zulkifley et al. (2014). The required quantities of OPC and MSF were added to the natural burnt peat soil and then mixed well until it is achieve homogeneity. The mixtures were placed in three (3) successive layers in an unconfined compression strength mold with an internal diameter of $38 \mathrm{~mm}$ and a minimum length/diameter ratio of 2. With the air curing technique, the samples of stabilized peat were kept at normal room temperature of $30 \pm 2{ }^{\circ} \mathrm{C}$ and out of reach of water intrusion during the curing period.

This technique was used to strengthen the stabilization of peat or organic soil samples by reduced of gradual moisture content, instead of the usual water curing and water submergence technique method which has been practiced of previous research for peat stabilized with addition of cement as described by Alwi (2008), Axelsson et al. (2002), Duraisamy et. al (2007), Janz and Johansson (2002), Kalantari dan Huat (2008), Wong (2010) and Zulkifley et al. (2014). Previous experiment conducted by Kalantari and Huat (2008) used air curing technique on peat stabilization by using polyproplyne fibers with cement 
and noticed more strength values, added uniformity and intactness to the stabilized peat itself. Zulkifley (2014) are utilizing the same method but adding distinctive type of filler which is mineral soil filler (clay, silt, sand); mineral soil is easier, cheaper and more appropriate to use as fillers as they are promptly accessible in situ/near the site.

\section{RESULTS AND DISCUSSION}

\section{FIELD IDENTIFICATION}

Description of peat sampled in the field was endeavoured utilizing the modified classification of Von Post method. From the field identification of the burnt peat soils samples, it has been observed that the peat soil is composed of slightly to highly decomposed peat ranging from $\mathrm{H} 3$ to $\mathrm{H} 8$ according to Von Post Degree of Humification Scale. Morphology of peat basin in study area are encountered as topogenous peat (locality MP-1; pt thickness $<150 \mathrm{~m}$ ) and ombrogenous peat (localities BP-a, Bp-1 and BP-4; pt thickness $>150 \mathrm{~m}$ ) with accumulation of burnt peat texture at the top layer of peat basin $(0.00 \mathrm{~m}-0.25 \mathrm{~m})$. The peat in study area generally can be categorized as fibric, fibric to hemic, hemic, hemic to sapric and sapric texture. The peat layers ranged from $0.45 \mathrm{~m}$ to $3.25 \mathrm{~m}$ thick, with the thickness is significantly increase north-west wards, whereas the fibrous content of peat is proportionally increase with depth thickness of peat basin. The peat encountered has a colour range of very dark reddish brown to dark brownish gray to grayish brown as followed by the Munsell Soil Colour Chart, with the color dissemination as follows: very dark reddish brown (5YR 2/3-4), brownish black to dark brown (5YR 3/1-2), dark reddish brown (5YR 3/2-3) and brownish grey to grayish brown (5YR 4/1-2) as described in Table 1. The groundwater levels in the northwest part of degraded area ranged $0.30 \mathrm{~m}$ to $0.60 \mathrm{~m}$ below the ground surface at logged locations MP-1, BP-a, BP-1 and BP-4 (Figure 2).

\section{IMPACT OF PEAT FIRES ON CEMENT-PEAT-STABILIZATION \\ DECOMPOSITION DEGREE}

Table 2 shows the results of degree of humification (according to Von Post Classification system) from field

TABLE 1. Description of peat sample near the surface from the peat basin periphery; margin (within point MP-1) to midsection (near location BP-a) towards the approximate centre of the peat basin (location BP-4) of the study area

\begin{tabular}{|c|c|c|c|c|}
\hline Auger Hole/Sample No & MP-1 & BP-a & BP-1 & BP-4 \\
\hline Location & $0 \mathrm{~m}$ & $300 \mathrm{~m}$ from $\mathrm{MP}$ & $600 \mathrm{~m}$ from MP & $900 \mathrm{~m}$ from $\mathrm{MP}$ \\
\hline Thickness of Peat (m) & 0.40 & 2.92 & 1.95 & 3.25 \\
\hline $\begin{array}{l}\text { Classification of peat } \\
\text { type with depth (Von } \\
\text { Post Classification) }\end{array}$ & $0.25-0.40 \mathrm{~m}: \mathrm{H} 8$ & $\begin{array}{l}0.25-0.50 \mathrm{~m}: \mathrm{H} 8-\mathrm{H} 9 \\
0.50-0.75 \mathrm{~m}: \mathrm{H} 6-\mathrm{H} 8 \\
0.75-1.25 \mathrm{~m}: \mathrm{H} 6-\mathrm{H} 7 \\
1.25-1.50 \mathrm{~m}: \mathrm{H} 3-\mathrm{H} 5 \\
1.50-2.92 \mathrm{~m}: \mathrm{H} 2-\mathrm{H} 3\end{array}$ & $\begin{array}{c}0.25-0.75 \mathrm{~m}: \mathrm{H} 7-\mathrm{H} 8 \\
0.50-0.75 \mathrm{~m}: \mathrm{H} 6-\mathrm{H} 7 \\
0.75-1.00 \mathrm{~m}: \mathrm{H} 5 \\
1.00-1.50 \mathrm{~m}: \mathrm{H} 3-\mathrm{H} 4 \\
1.50-1.95 \mathrm{~m}: \mathrm{H} 2-\mathrm{H} 3\end{array}$ & $\begin{array}{c}0.25-0.50 \mathrm{~m}: \mathrm{H} 8 \\
0.50-0.75 \mathrm{~m}: \mathrm{H} 7-\mathrm{H} 8 \\
0.75-1.25 \mathrm{~m}: \mathrm{H} 5-\mathrm{H} 7 \\
1.25-1.50 \mathrm{~m}: \mathrm{H} 3-\mathrm{H} 5 \\
1.50-3.25 \mathrm{~m}: \mathrm{H} 3\end{array}$ \\
\hline $\begin{array}{l}\text { Classification/ Type of } \\
\text { peat with depth }\end{array}$ & 0.25-0.40 m: Sapric & $\begin{array}{c}\text { 0.25-0.50 m: Sapric } \\
0.50-0.75 \mathrm{~m}: \text { Sapric to } \\
\text { Hemic } \\
0.75-1.25 \mathrm{~m} \text { : Hemic } \\
1.25-1.50 \mathrm{~m}: \text { hemic to } \\
\text { Fibric } \\
1.50-2.92 \mathrm{~m}: \text { Fibric }\end{array}$ & $\begin{array}{c}0.25-0.50 \mathrm{~m}: \text { Sapric } \\
0.50-0.75 \mathrm{~m}: \text { Sapric to } \\
\text { Hemic } \\
0.75-1.00 \mathrm{~m}: \text { Hemic } \\
1.00-1.50 \mathrm{~m}: \text { Hemic to } \\
\text { Fibric } \\
1.50-1.95 \mathrm{~m}: \text { Fibric }\end{array}$ & $\begin{array}{c}0.25-0.50 \mathrm{~m}: \text { Sapric } \\
0.50-0.75 \mathrm{~m}: \text { Sapric to } \\
\text { Hemic } \\
0.75-1.25 \mathrm{~m}: \text { Hemic } \\
1.25-1.50 \mathrm{~m}: \text { Hemic to } \\
\text { Fibric } \\
1.50-3.25 \mathrm{~m}: \text { Fibric }\end{array}$ \\
\hline $\begin{array}{l}\text { Groundwater level } \\
\text { (Distance from surface) }\end{array}$ & - & 0.30 & 0.45 & 0.60 \\
\hline $\begin{array}{l}\text { Colour of peat (Munsell } \\
\text { colour code) }\end{array}$ & $0.25-0.40 \mathrm{~m}: 5 \mathrm{YR} 3 / 1-2$ & $\begin{array}{l}0.25-0.50 \mathrm{~m}: 5 Y R 3 / 2-3 \\
0.50-0.75 \mathrm{~m}: 5 Y R 3 / 2-3 \\
0.75-1.25 \mathrm{~m}: 5 Y R 3 / 1-2 \\
1.25-1.50 \mathrm{~m}: 5 Y R 3 / 1-2 \\
1.50-2.92 \mathrm{~m}: 5 Y R 3 / 2-3 \\
\quad-5 Y R 3 / 1-2\end{array}$ & 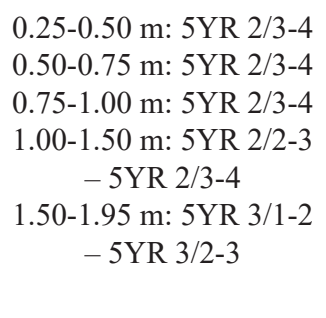 & 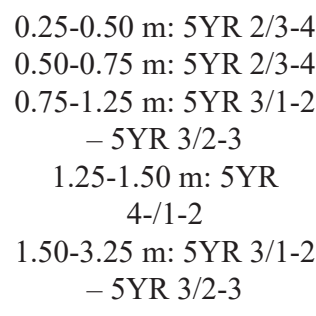 \\
\hline $\begin{array}{l}\text { Elevation (Garmin } \\
\text { GPS) }\end{array}$ & $17 \mathrm{~m}$ & $16 \mathrm{~m}$ & $12 \mathrm{~m}$ & $18 \mathrm{~m}$ \\
\hline Peat depth & Shallow & Deep & Medium to deep & Very deep \\
\hline $\begin{array}{l}\text { Peat type } \\
\text { (Paramananthan, 2011) }\end{array}$ & Topogenous & Ombrogenous & Ombrogenous & Ombrogenous \\
\hline
\end{tabular}




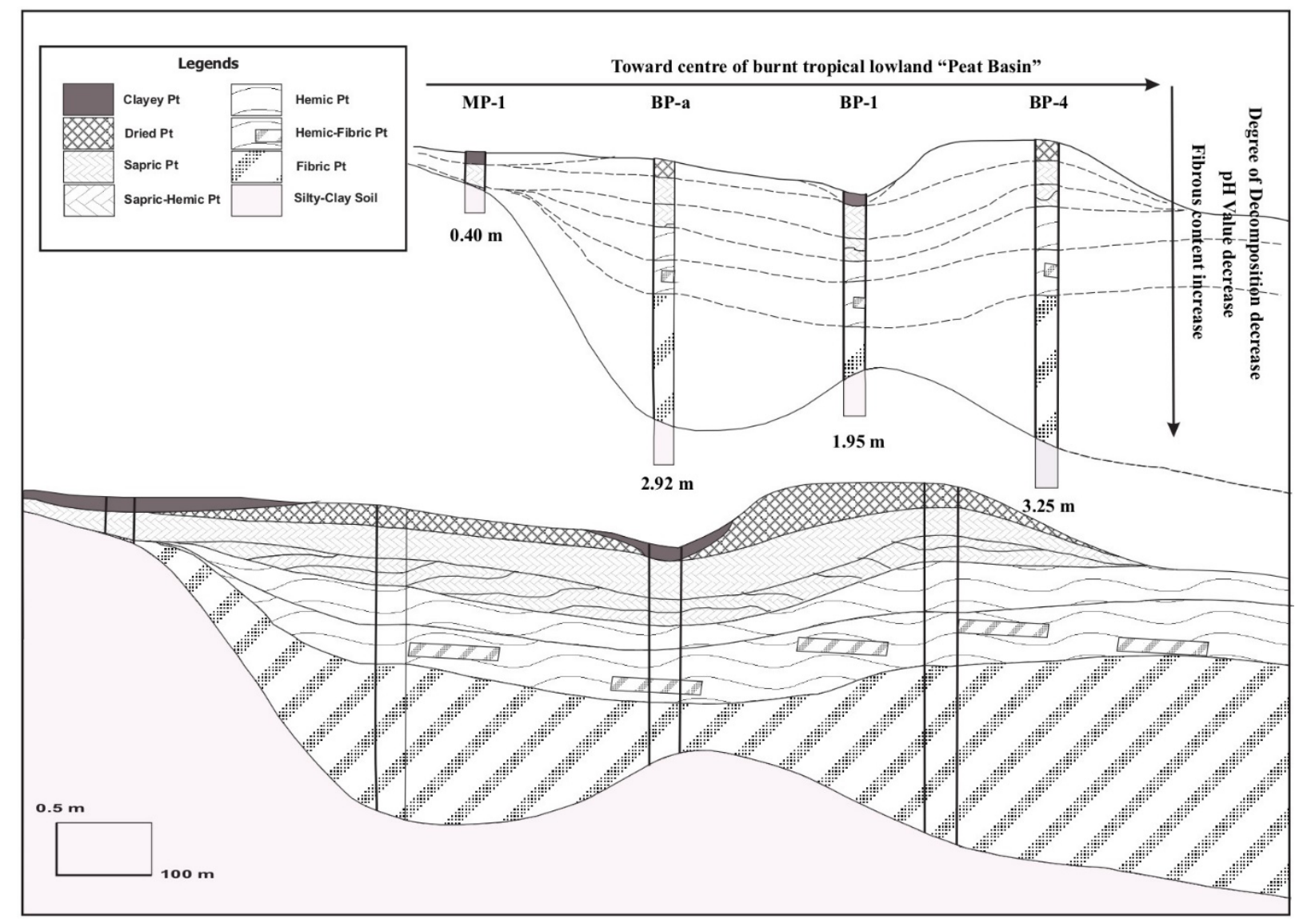

FIGURE 2. Location of peat cores point MP-1, BP-a, BP-1 and BP-4 within the peat basin/deposit, thickness of the peat and detail classification of the types of peat (sapric to fabric) derived from field observation

identification and Unconfined Compressive Strength yielded from the analysis after 28 days of air-curing stabilization. It is obviously seen that the samples tested from locality BP-a and BP-1 gaining the highest unconfined compressive strength with $430.17 \mathrm{kPa}$ (Sapric Pt with presence of burnt peat structure; H9) and 412.17 $\mathrm{kPa}$ (Sapric Pt with presence of burnt peat structure; H8), respectively. In contrast, specimens from locality BP-6 yielded the lowest strength of UCS with $149.59 \mathrm{kPa}$ (Hemic to Fibric Pt; H4-H5). The decrease of unconfined compressive strength value is depending on the degree of decomposition of peat. The decomposition degree of tropical peat is typically structured upon the peat-forming environment. Peat formed in humid surroundings decomposes slowly ensuing in a low decomposition degree. In contrast, peat soil in a dry and hot climate is much more likely to be rather decomposed (Jinming \& Xuehui 2009). Generally, temperature factor impacts the movement and regenerate limit of soil organisms, accordingly affecting the decay rate of plant debris. Under high temperature conditions, compound activity is more grounded and the soil organism recreate rapidly, with the goal that disintegration of plant debris is accelerated (Xintu 2009). Tropical peat soil on the surface is more prone to high heat temperatures resulting in higher degree of decomposition/humification. Based on the results in the table, the strength of UCS on cement-filler-peat stabilization at surface area is higher than stabilized peat at deeper depth. Peat humification reduces the percentage of large pores with the aid of breaking down plant particles into smaller fragments, thereby decreasing the interparticle pore spaces (Bragazza et al. 2008; Moore et al. 2005). The combination of high decomposition degree of peat will enhance cement-mineral soil filler stabilized peat samples. According to Moayedi and Mosallanezhad (2017), the impact of Ordinary Portland cement was excessive on sapric-type peat due to its physico-chemical characterization.

Decomposition is necessary to produce harder (sample when dried) amorphous grains (from decomposed hardwood fragment) and would be incorporated into interconnected matrix of hardened tobermorite gel (from primary cement hydration reaction), filler (natural or added mineral soil filler of sand/clay/silt) to give dried stabilized mixture as result the higher stabilization strength (Zulkifley et al. 2014). All the samples tested particularly specimens from location BP-a and BP-1 gain a high UCS value due to very strong degree of decomposition with value H8-H9 according to modified Von Post Classification system. In contrast, point BP-6 yielded give a lower UCS strength of $123.33 \mathrm{kPa}$ with decomposition level perceived is $\mathrm{H} 4$ (slightly decomposed). 
Zulkifley et al. (2014) expressed a combination factors such as vegetational zonation (phasic group) and related high level of decay rate (sapric or hemic to sapric), resulting in the nearness of hard undefined grains likewise give the impact of the strength of the cement-stabilized tropical lowland peats (additionally to the impacts of the percentage of natural mineral soil content that happen in situ/in the field or option of filler as clay, silt sediment or fine grained sand). The differences in forest structure might depend on peat depth (thickness) and peat characteristics (Anderson 1964; Melling et al. 2006; Page et al. 1999). The peat of study area generally shows a significant decreasing in decomposition rate (highly decomposed to less decomposed) from marginal peat towards the centre of peat basin. The proposed phasic community vegetation succession is classifying as phasic community I (Mixed Swamp Forest) and II (Alan Swamp
Forest) and might reached to phasic community I (Padang Alan Forest) according to field observation on peat texture. Mixed Peat Swamp Forest is generally has most decomposed peat and found in lower elevation (near to mineral soil substratum). In contrast, Alan Swamp Forest is woodiest peat that dominantly recognized on stress environment while Padang Alan Forest is usually found in flatter topography with less decomposed peat. Henceforth, vegetational zonation occurring may be conducive to lowland tropical peat stabilization due to vegetational progression produces with hardwood that normally create the hard, undefined grains that detain the strength of the settled peat upon the continuous drying and solidifying of the cement in form of tobermorite/ Calcium Silicate Hydrate (CSH) gel-filler-peat mix with an interconnection of soil structure/matrix amid the process of stabilization.

TABLE 2. The description of degree of humification/decomposition according to Von Post Classification and Unconfined Compressive Strength (UCS) results after 28 days curing time

\begin{tabular}{|c|c|c|c|c|}
\hline Sample location & Soil description & Von Post System & Hue Value & $\begin{array}{l}\text { UCS Strength (After } \\
28 \text { Days Curing, Kpa) }\end{array}$ \\
\hline MP-1 & $\begin{array}{l}\text { Brownish gray to grayish brownish grayish brown } \\
\text { SAPRIC PEAT with some admixture of of clayey } \\
\text { soil deposit. Moist. } 1 / 3 \text { to } 2 / 3 \text { residue left in hand. } \\
\text { Decomposition is very strong wood fragment } 10- \\
20 \%\end{array}$ & H8 & $5 Y R 3 / 1-2$ & 170.93 \\
\hline BP-a & $\begin{array}{l}\text { Dark reddish brown SAPRIC PEAT with some } \\
\text { presence of burnt peat structure. Moist to } \\
\text { wet. Brown paste with slightly dark brownish } \\
\text { muddy water extruded. } 1 / 3 \text { residue left in hand. } \\
\text { Decomposition is practically fully decomposed. } \\
\text { Wood fragment } 5-10 \%\end{array}$ & H9 & $5 Y R 3 / 2-3$ & 430.17 \\
\hline BP-1 & $\begin{array}{l}\text { Very dark reddish brown SAPRIC PEAT with } \\
\text { some clayey soil deposit. Dark brown muddy } \\
\text { water extruded. Wet. } 2 / 3 \text { residue left in hand. } \\
\text { Decomposition is strong to very strong. Wood } \\
\text { fragments } 10-15 \%\end{array}$ & $\mathrm{H} 7-\mathrm{H} 8$ & $5 Y R 2 / 3-4$ & 267.33 \\
\hline BP-2 & $\begin{array}{l}\text { Dark reddish brown SAPRIC PEAT with some } \\
\text { presence of burnt peat structure. Moist to Wet. } 1 / 3 \\
\text { residue left in hand. Decomposition is very strong. } \\
\text { Wood fragment } 5 \%-10 \%\end{array}$ & H8 & $5 Y R 3 / 2-3$ & 412.17 \\
\hline BP-3 & $\begin{array}{l}\text { Dark reddish brown SAPRIC PEAT with some } \\
\text { presence of burnt peat structure. Moist to Wet. } 1 / 3 \\
\text { residue left in hand. Decomposition is strong to } \\
\text { very strong. Wood fragment } 10-15 \%\end{array}$ & $\mathrm{H} 7-\mathrm{H} 8$ & $5 Y R 3 / 2-3$ & 329.66 \\
\hline BP-4 & $\begin{array}{l}\text { Very dark reddish brown SAPRIC PEAT with } \\
\text { some presence of burnt peat structure. Wet. } 2 / 3 \\
\text { residue left in hand. Decomposition is moderately } \\
\text { strong. Wood fragment } 5-8 \%\end{array}$ & $\mathrm{H} 7-\mathrm{H} 8$ & $5 Y R 2 / 3$ & 150.92 \\
\hline BP-5 & $\begin{array}{l}\text { Very dark reddish brown SAPRIC to HEMIC } \\
\text { PEAT. Wet to saturated. } 2 / 3 \text { to } 3 / 3 \text { residue left in } \\
\text { hand. Decomposition is moderately strong. Wood } \\
\text { fragment } 25-30 \%\end{array}$ & H6-H7 & $5 Y R 2 / 4$ & 183.02 \\
\hline BP-6 & $\begin{array}{l}\text { Brownish black to dark reddish brown HEMIC } \\
\text { to FIBRIC PEAT. Wet to saturated. } 2 / 3 \text { TO } 3 / 3 \\
\text { residue left in hand. Decomposition is slightly } \\
\text { decomposed. Wood fragment } 40-45 \%\end{array}$ & $\mathrm{H} 4-\mathrm{H} 5$ & $5 \mathrm{YR} 2 / 2-3$ & 149.59 \\
\hline
\end{tabular}




\section{PHYSICO-CHEMICAL PROPERTIES}

The results of index properties of selected burnt peat soils sampled from various distance from marginal peat area towards centre of peat basin at point MP-1 to BP-6 were explained in Table 3. In this study, silty-clay mineral soil was chosen as filler collected from a nearby location from the $0.00 \mathrm{~m}$ to $0.50 \mathrm{~m}$ sampling interval. Generally, peat has well recognized as organic soil with high natural moisture content due to its natural water-holding capacity. The high natural water holding capacity of peat soil is due to the structure of soil that have characterized by organic coarse particles (known as fiber) which can hold a considerable amount of water since the soil fibers are very loose and hollow (Huat et al. 2011). From the result in Table 4, the value of natural moisture content at burnt peat area has ranged between 354 and $709 \%$, as suggested by Huat (2004) that moisture content range values of peat soil of West Malaysia are between 200 and 700\%. All peat samples tested from burnt peat areas are very to medium acidic with $\mathrm{pH}$ ranging from 3.18-5.60. In geotechnical engineering aspect, organic soils with organic content that greater than $75 \%$ are known as 'peats' (Huat 2004). From the result, all of the burnt peat soil samples contain more than $75 \%$ of organic matter with less than $25 \%$ of ash content. Generally, the entire sample tested showing a consistent increase from 14 days to 28 days curing period with range $110.17 \mathrm{kPa}-245.30 \mathrm{kPa}$ (14 days) and 146.59 $\mathrm{kPa}-412.17 \mathrm{kPa}$, respectively.

Ordinarily, the volumes of peat samples were higher in wet condition and started to decrease when it getting dried and shrunk. As shown in Figure 3, the value of shrinkage limit is getting higher with increasing of moisture content of burnt peat soil. This create apparent shrinkage for high organic content (high porosity) thus stabilized peat near to basin centre as compared to medium high organic content (lower porosity) in the marginal and transitional peat area. The high organic content usually produces higher porosity compare to other type of soils. With addition of Ordinary Portland Cement (binder) and mineral soil (filler), it might fill the air void of grain particles; thus the tendency of stabilized burnt peat can be reduced. The linear shrinkage was significantly reduced by the addition of admixture and curing period of stabilized peat with addition of mineral soil filler particles. It is also perceptible that the strength of UCS of burnt peat sample layer is greater compared to ordinary peat soil (undisturbed peat layer). This may attribute the contribution of organic material; where organic material changed its structure from the fire event, thus, the capability of the soil to hold water particles is reduced and yielded higher UCS strength of cementfiller-peat stabilization. The result also suggested maximum of water content of burnt peat to yield the maximum strength of unconfined compressive strength $\left(\mathrm{q}_{\mathrm{u}}\right)$ is range between 318 and $379 \%$. This a sensible as the principle of utilizing the air curing technique for strengthening stabilized peat is that the natural moisture contains of peat soil content adequate water with range from $198 \%$ to $417 \%$ for curing process take place when the peat is mixed with cement (Kalantari \& Huat 2008).
Mostly the range of acidity level in peat soil is wide, which is 2 to 6 but in some condition where there is penetration of saline water or contain pyritic materials the $\mathrm{pH}$ can be as high as 7.8 or not exactly 2 , separately (Andriesse 1988). From the result, the range of $\mathrm{pH}$ test is range 3.3 to 5.6 indicating medium acidity level. Acidity of peat and organic soil in degraded area at Banting, Selangor Malaysia was found to be directly correlated to the decomposition rate. Generally, the factors that affect the chemical properties of peat is peat type, peat thickness, topography and hydrology (Tie \& Kueh 1979). Murayama and Zahari (1996) stating a hypothesis; the higher the $\mathrm{pH}$ level, the greater the decomposition/ humification rate of peat soil. All samples tested are very acidic with $\mathrm{pH}$ ranging from 3.18-5.60. Variation within this range are caused either by combination of in situ mineral soil which usually increase the $\mathrm{pH}$ reading level or by specific locality in the peat swamp (Andriesse 1988). The presence of organic acid in peat soil may cause the value of $\mathrm{pH}$ tend to drop, decreasing the rate reaction of hydration of the cement binder, then give the slower strength gain in peat soil (Axelsson et al. 2002; Wong 2010). As mentioned by Kazemian et al. (2010), an acidic medium (pH3, 5) during the curing results in easy contact with cement in fibrous peat and restrain hydration and pozzolanic reactions.

The $\mathrm{pH}$ value of the pore solution is important aspect in hydration process; when the value of $\mathrm{pH}$ is lower than 9, the hydration products are dissolved and there is no or low hardening produce, as result weak strength of the peat samples. Besides, if acid in peat was not neutralized completely by sufficient binder, the acid will strongly retard the hydration process and secondary pozzolanic reactions due to strong chemical affinity to calcium liberated from the hydrolysis of cement. Unless an extensive amount of concrete is blended with the soil for stabilization adjustment, the blend of natural acids, soil and cement creates a $\mathrm{pH}$ lower than 9 in the pore arrangement, which is too low to allow auxiliary mineral cementation product development in this way hinders the stabilization impact (Tremblay et al. 2002; Wong 2010). In addition, higher value of $\mathrm{pH}$ (alkaline), the shear strength of stabilized peats increased due to the $\mathrm{OH}$ - ions liberated during the hydration process and produce CSH gel easily during curing process (Kazemian et al. 2010). Thus, it is clearly shown, there are significant strength increase in cement-stabilized burnt peat that attributed to the physio-chemical reactions that occur through hydration reaction, the hardening process of cement paste and the interaction between soil substances and the primary and cementation hydration product (Zulkifley 2014). It is also noticeable from the result that the value of ash content is directly proportional with $\mathrm{pH}$ value which is the higher the ash content, the higher is the value of $\mathrm{pH}$. This is reasonable as the value of $\mathrm{pH}$ increase with the accumulation of ash compound (Wood \& Balfour 2010) and the increasing of ash compound will affects the strength of cement-peat-stabilization. 
Natural Moisture Content (\%)

$\begin{array}{lllllllllllllllllll}134 & 165 & 195 & 226 & 257 & 287 & 318 & 348 & 379 & 410 & 438 & 469 & 499 & 530 & 560 & 591 & 622 & 652 & 683\end{array}$

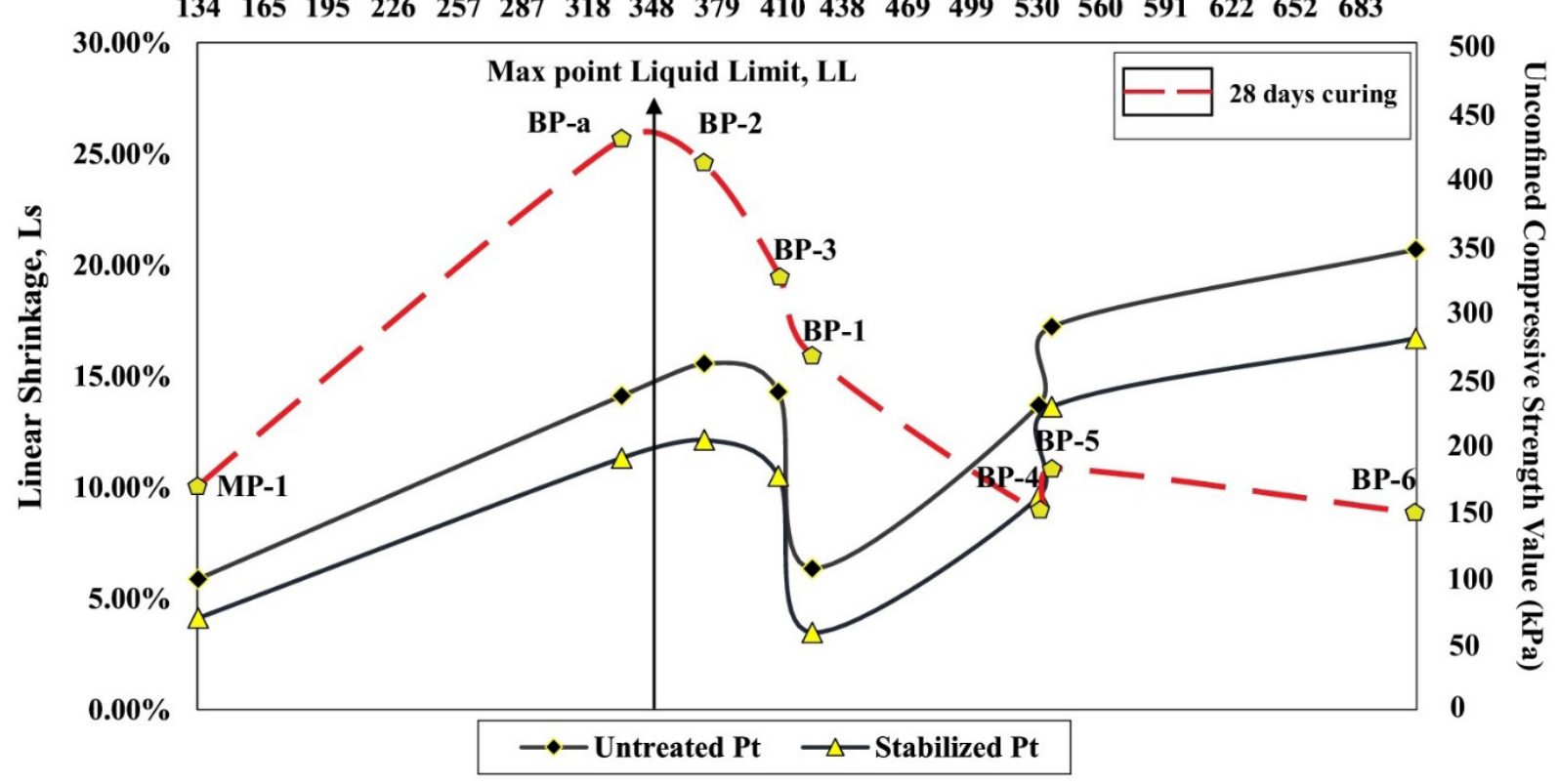

FIGURE 3. The relationship between Natural Moisture Content (\%) with Unconfined Compressive Strength Value (kPa) and linear shrinkage limit (Ls) of burnt peat sample at point MP-1 to BP-6

TABLE 3. The results of physical and engineering properties of burnt peat and original (undisturbed) tropical lowland peat samples of Busut Baru Village area, Banting of the state of Selangor, Malaysia

\begin{tabular}{|c|c|c|c|c|c|c|c|c|c|}
\hline \multirow[t]{3}{*}{ Sample } & \multirow{3}{*}{$\begin{array}{l}\text { Natural } \\
\text { moisture } \\
\text { content }\end{array}$} & \multirow[t]{3}{*}{$\begin{array}{l}\text { Organic } \\
\text { content }\end{array}$} & \multirow[t]{3}{*}{$\begin{array}{c}\text { Ash } \\
\text { content }\end{array}$} & \multicolumn{2}{|c|}{$\mathrm{pH}$ Value } & \multicolumn{2}{|c|}{ Shrinkage limit } & \multirow{2}{*}{\multicolumn{2}{|c|}{$\begin{array}{c}\text { Unconfined compressive } \\
\text { strength, qu (kPa) } \\
\text { Curing (day) }\end{array}$}} \\
\hline & & & & untreated $\mathrm{Pt}$ & treated $\mathrm{Pt}$ & untreated $\mathrm{Pt}$ & Treated Pt & & \\
\hline & & & & & & & & 14 & 28 \\
\hline MP-1 & 134.38 & 68.12 & 31.88 & 4.05 & 11.08 & $5.88 \%$ & $4.12 \%$ & 110.73 & 170.93 \\
\hline BP-a & 334.76 & 91.06 & 8.94 & 3.18 & 9.42 & $14.12 \%$ & $11.32 \%$ & 230.77 & 430.17 \\
\hline BP-1 & 424.98 & 88.61 & 11.39 & 5.60 & 10.78 & $6.35 \%$ & $3.47 \%$ & 138.21 & 267.33 \\
\hline BP-2 & 373.23 & 94.47 & 5.53 & 3.36 & 10.77 & $15.57 \%$ & $12.13 \%$ & 193.00 & 412.17 \\
\hline BP-3 & 408.34 & 93.65 & 6.35 & 3.31 & 9.58 & $14.30 \%$ & $10.52 \%$ & 245.30 & 329.66 \\
\hline BP-4 & 531.14 & 86.64 & 13.36 & 3.88 & 10.67 & $13.70 \%$ & $9.58 \%$ & 130.21 & 150.92 \\
\hline BP-5 & 537.91 & 87.29 & 12.71 & 3.65 & 10.68 & $17.22 \%$ & $13.62 \%$ & 150.95 & 183.02 \\
\hline BP-6 & 709.80 & 78.96 & 21.04 & 4.12 & 11.00 & $20.70 \%$ & $16.70 \%$ & 123.33 & 149.59 \\
\hline
\end{tabular}

\section{LATERAL VARIATION}

The results of Unconfined Compressive Strength (UCS) analysis of peat fire and organic soils sample from degraded area of Banting, Selangor are shown in Table 3. Peat fire samples are collected from the margin area towards to the centre of peat basin. Figure 4 shows the relationship between the strength yielded from UCS analysis and the axial/vertical strain of stabilized cement-filler-peat admixture specimens with fixed composition amount (20 $\mathrm{g}$ OPC, $25 \mathrm{~g}$ MSF and $100 \mathrm{~g}$ raw peat fire) but with different location at varying distances from the basin margin (shallow peat basin) to the centre (deeper thickness).

After 14 and 28 days of curing time period, the two (2) samples were tested in triplicate, sampled from BP-a and BP-2 with sapric (H8-H9, according to Von Post Classification system), very strong to practically fully decomposed from middle section between the basin margin (shallow peat) and the centre (deeper thickness) were yielded the highest average of UCS strength of $230.77 \mathrm{kPa}$ and $193.00 \mathrm{kPa}$ for 14 days curing and 430.17 $\mathrm{kPa}$ and $412.17 \mathrm{kPa}$ for 28 days curing, respectively (Figure 5). Otherwise, the specimen from the sample collected near to the basin centre, with sapric, sapric to hemic and hemic to fibric peat type from auger locations BP-4, BP-5 and BP-6 had created a lower average UCS strength with $130.21 \mathrm{kPa}, 150 \mathrm{kPa}$ and $123.33 \mathrm{kPa}$ for 14 days and relatively increased as much as 28 days curing period with $150.92 \mathrm{kPa}, 183.02 \mathrm{kPa}$ and $149.59 \mathrm{kPa}$, 
respectively. In contrast, the topogenic or shallow peat near the margin of peat basin yielded lower strength of UCS value with $110.73 \mathrm{kPa}$ (14 days) and $170.93 \mathrm{kPa}$ (28 days). According to Zulkifley et al. (2014a), the lateral variation in the peat humification levels is relatively occurred from margin toward the center or near-center areas of the tropical lowland peat basin. Topogenous or shallow peat that composed of plant debris with clastic sediment normally yielded greater compressive strength. The mineral soil content in the shallow peat (in combination form of clay, silt and sand) will performing as natural filler or stiffener and enhance the UCS estimation of peat-cement-stabilization. In assessment, the ombrogenic or deeper peat layer have lower Unconfined Compressive Strength due to relatively lower mineral soil content (Zulkifley et al. 2014). However, the hydration process cannot be derived since there is insufficient moisture to soil interacts with Ordinary Portland Cement to form cement paste containing essential cementation product that solidify to create a system of interlocking crystal that cohere the material together.

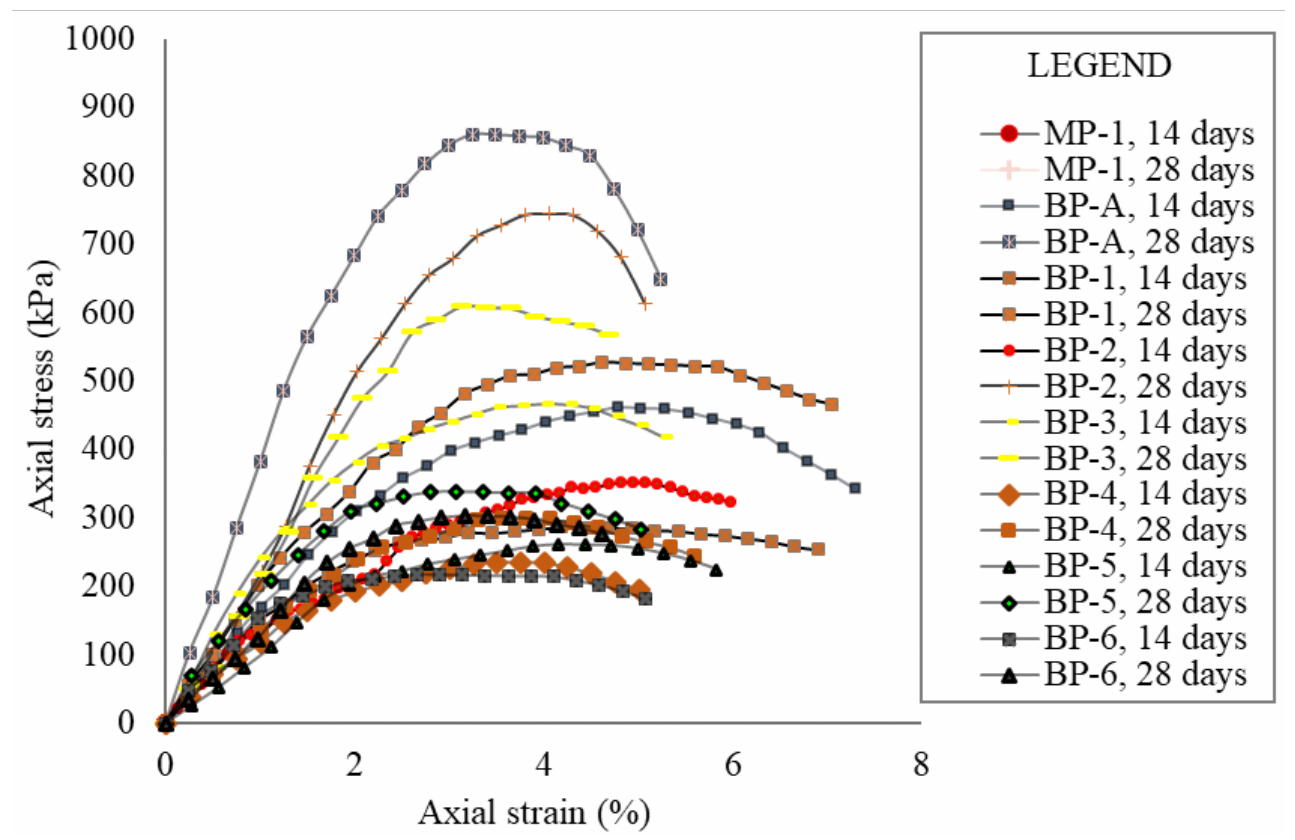

FIGURE 4. The relationship between Unconfined Compressive Strength value, qu $(\mathrm{kPa})$ and axial strain $(\%)$ of cement-mineral soil filler-peat stabilization with the same composition (20 g Ordinary Portland Cement, $25 \mathrm{~g}$ mineral soil filler and $100 \mathrm{~g}$ wet peat) from varying distance from the marginal basin towards centre

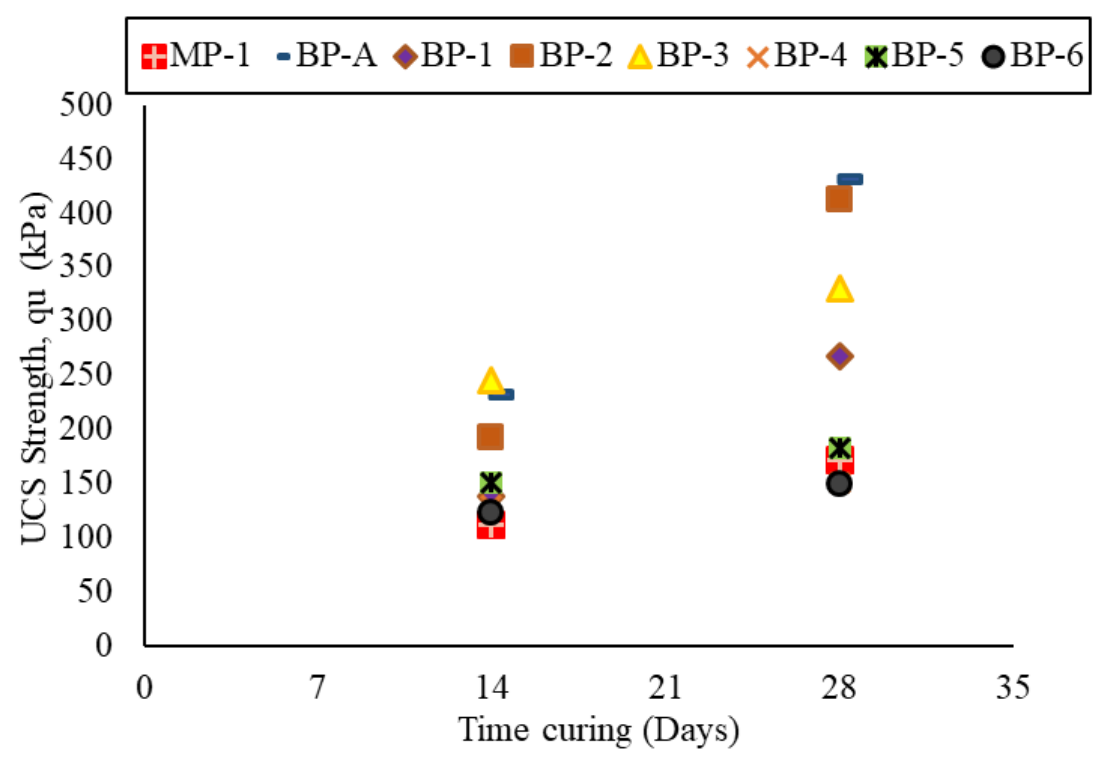

FIGURE 5. The comparison of Unconfined Compressive Strength result with time curing of burnt peat soil samples at point MP-1 to BP-6 


\section{CONCLUSION}

The identification of the studied area indicates there is lateral variation occur in peat decomposition levels in the range of dominantly sapric, sapric to hemic, hemic, hemic to fibric and fibric peat textures with some accumulation of dried peat resulting from fire event at upper layer of the basin. The fibrous content of peat is proportionally increased with thickness of peat basin. Fire event normally affects the physical and chemical properties of the peat soil. It also noticeable that the strength of UCS of burnt peat sample layer is greater compared to ordinary peat soil (undisturbed peat layer). The organic material is changed its physical structure resulting from the fire event, thus the capability of the soil to hold water particles has decreased and yielded higher UCS strength of cement-peatstabilization. The value of of ash content is directly proportional with $\mathrm{pH}$ value as the accumulation of ash compound. Otherwise, the quantity of ash content literally effects the strength of cement-peat-stabilization as accumulation of ash will enhance the $\mathrm{pH}$ value and yielded greater compressive strength. This research is proposing the maximum of water content of burnt peat to yield the maximum strength of Unconfined Compressive Strength (qu) is range between 318 and $379 \%$ due to low water retention of peat soil resulting from the fire event. The findings also suggest that lateral variation within the peat basin indirectly affects the strength of cement-peatstabilization. Topogenous or shallow peat that composed of plant debris with clastic sediment yielded lower value of unconfined compressive strength due to insufficient of moisture content. Mineral soil content in shallow peat (in admixture form of clay, silt, and fine grained sand) will performing as natural filler or stiffener and enhance the UCS estimation of peat-cement-stabilization. The strength of burnt peat can be considerably improved by stabilization. The most important geotechnical aspect of peat that effect on stabilization process are natural water content, humification grade, ash content, and $\mathrm{pH}$ value.

\section{ACKNOWLEDGEMENTS}

The authors extend their gratitude to the late Dr. Mohamad Tarmizi bin Mohamad Zulkifley and all the reviewers that contributed by their invaluable comments to improve this manuscript. We also recognize the IPPP grant BK064-2015 and grant RF022B-2018 under Pusat Pengurusan Geran Penyelidikan (PPGP), University Malaya (Kuala Lumpur, Malaysia) for financial support of the research.

\section{REFERENCES}

Alwi, A. 2008. Ground improvement of Malaysian peat soils using stabilized peat-column techniques. PhD Thesis. University of Malaya (Unpublished).

Anderson, J.A.R. 1964. The structure and development of the peat swamps of Sarawak and Brunei. J. Trop. Geogr. 18: 7-16.

Andriesse, J.P. 1988. Nature and Management of Tropical Peat Soils. 1st ed. Rome: FAO.
ASTM. 2007. Standard Test Methods for Moisture, Ash, and Organic Matter of Peat and Other Organic Soils. American Society for Testing and Material. ASTM Standard D2974 $-07 a$.

Axellson, K., Johansson, S.E. \& Andersson, R. 2002. Stabilization of Organic Soils by Cement and Puzzolanic Reactions. Feasibility Study, Linkoping (Sweden). 3rd report of Swedish Deep Stabilization Research Centre.

Bragazza, L., Buttler, A., Siegenthaler, A. \& Mitchell, E.A.D. 2008. Plant litter decomposition and nutrient release in peatlands. In Carbon Cycling in Northern Peatlands, edited by Baird, A., Belyea, L., Comas, X., Reeve, A.S. \& Slater, L.D. Geophysical Monograph Series 184: 99-110.

BS 1377: Part 2. 1990. Methods of Test for Soils for Civil Engineering Purposes, Classification Tests. British Standard Institute.

BS 1377: Part 7. 1990. Methods of Test for Soils for Civil Engineering Purposes. Shear Strength Tests Total Stress. British Standard Institute.

Duraisamy, Y., Huat, B.B.K. \& Aziz, A.A. 2007. Compressibility behaviour of tropical peat reinforced with cement columns. Am. J. Appl. Sci. 4(10): 786-791.

Huat, B.B.K. 2004. Organic and Peat Soil Engineering. Serdang: Universiti Putra Malaysia Press.

Huat, B.B.K., Kazemian, S., Prasad, A. \& Barghchi, M. 2011. State of an art review of peat: General perspective. International Journal of the Physical Sciences 6(8): 19881996.

Janz, M. \& Johansson, S.E. 2002. The Function of Different Binding Agents in Deep Stabilization. Linkoping (Sweden): 9th Report of Swedish Deep Stabilization Research Centre.

Jinming, H. \& Xuehui, M. 2009. Physical and chemical properties of peat. In Coal, Oil, Shale, Natural Bitumen, Heavy Oil and Peat (Vol II), Encyclopedia of Life Support Systems. EOLSS Publications. pp. 309-327.

Kalantari, B. \& Huat, B.B.K. 2008. Peat soil stabilization, using ordinary Portland cement, porypropylene fibers, and air curing technique. Electronic Journal of Geotechnical Engineering 13: 1-13.

Kazemian, S., Huat, B.B.K., Thamer, A., Ahmad, A. \& Farah, N.A.A. 2010. The acidic and alkaline peat nature effect on cementation and pozzolanic reactions in cement column. 3rd International Conference on Problematic Soils, April 7-9, Adelaide, Australia. pp. 191-196.

Kon, T.W., Bong, C.F.J., King, J.H.P. \& Leong, C.T.S. 2012. Biodiversity oftermite (Insecta: Isoptera) in tropical peat land cultivated with oil palms. Pak. J. Biol. Sci. 15: 108120.

Melling, L. 2016. Peatland in Malaysia. In Tropical Peatland Ecosystem, edited by Mitsuru, O. \& Nobuyuki, T. Sapporo, Japan: Springer. pp. 59-70.

Mineral and Geoscience Department. 2007. Guideline for Engineering Geological Investigation in Peat and Soft Soils by the Engineering Geology Working Group. Mineral and Geoscience Department of Malaysia.

Moore, T.R., Trofymow, J.A. \& Prescott, S.M. 2005. Patterns of decomposition and carbon, nitrogen and phosphorus dynamics of litter in upland forest and peatland sites in Central Canada. Can. J. For. Res. 35(1): 133-142.

Moayedi, H. \& Mosallanezhad, M. 2017. Physico-chemical and shrinkage properties of highly organic soil treated with nontraditional additives. Geotech. Geol. Eng. 35: 1-11.

Murtedza, M., Padmanabhan, E., Mei, B.L.H. \& Siong, W.B. 2002. The peat soils of Sarawak. University Malaysia 
Sarawak, Sarawak, Malaysia. Individual partner report. In STRAPEAT (Strategies for Implementing Sustainable Management of Peatlands in Borneo) Status Report (March 2002).p. 16

Murayama, S. \& Zahari, A.B. 1996. Decomposition of tropical peat soils. JARQ 30: 45-151.

Nuruddin, A., Leng, H.M. \& Basaruddin, F. 2006. Peat moisture and water level relationship in tropical peat swamp forest. $J$. Appl. Sci. 6: 2517-2519.

Page, S.E., Rieley, J.O., Shotyk, O.W. \& Weiss, D. 1999. Interdependence of peat and vegetation in a tropical peat swamp forest. Phil. Trans. R. Soc. Lond. B. 354: 1885-1897.

Paramananthan, S. 2011. Keys to Identification of Malaysian Soils using Parent Materials (Mimeo). 2nd ed. Param Agricultural Soil Survey (M) Sdn. Bhd.

Paramananthan, S., Zauyah, S., Lim, C.P., Chan, Y.K. \& Boaklan, D. 1984. Proposals for a unified classification of organic soils in Malaysia. Proc. Workshop on Classification and Management of Peat in Malaysia, MSSS.

Rein, G., Cleaver, N., Ashton, C., Pironi, P. \& Torero, J.L. 2008. The severity of smouldering peat fires and damage to the forest soil. Catena 74: 304-309.

Tie, Y.L. \& Kueh, H.S. 1979. A review of lowland organic soils of Sarawak. Technical paper No. 4 Sarawak, Malaysia, Research Branch, Department of Agriculture.

Usup, A., Hashimoto, Y., Takahashi, H. \& Hayasaka, H. 2004. Combustion and thermal characteristics of peat fire in tropical peatland in Central Kalimantan, Indonesia. Tropics 14: 1-19.

Von Post, L. 1922. Sveriges geologiska undersoknings torvinventering och nagre av dess hittills vunna resultat. $\mathrm{Sr}$. Mosskulturfor. Tidskr 1: 1-27.

Wong, L.S. 2010. Stabilization of peat by chemical binders and siliceous sand. PhD Thesis, University of Malaya (Unpublished).

Wood, S.W. \& Balfour, V.N. 2010. The effects of soil texture and ash thickness on the post-fire hydrological response from ash-covered soils. Journal of Hydrology 392(3-4): 1423.

Xintu, L. 2009. Condition of peat formation. Encyclopedia of Life Support Systems. pp. 298-308.

Yule, C.M. 2010. Loss of biodiversity and ecosystem functioning in Indo-Malayan peat swamp forests. Biodivers. Conserv. 19: 393-409.

Zulkifley, M.T.M. 2014. Peat stabilization, organic geochemistry and related palynological characteristics of a tropical lowland peat basin in the Kota Samarahan-Asajaya Area, West Sarawak, Malaysia. Ph.D. Thesis. University of Malaya (Unpublished).

Zulkifley, M.T.M., Fatt, N.T., Raj, J.K., Hashim, R. \& Ashraf, M.A. 2014. The effects of lateral variation in vegetation and basin dome shape on tropical lowland peat stabilization in the Kota Samarahan-Asajaya area, West Sarawak, Malaysia. Acta Geologica Sinica 88(3): 894-914.

Azlan Shah Nerwan Shah* \& Khairul Azlan Mustapha

Department of Geology

Faculty of Science

University of Malaya

50600 Kuala Lumpur, Federal Territory

Malaysia

Roslan Hashim

Department of Civil Engineering

Faculty of Engineering

University of Malaya

50600 Kuala Lumpur, Federal Territory

Malaysia

*Corresponding author; email: azlansnerwans92@gmail.com

Received: 17 April 2019

Accepted: 23 November 2019 
